\title{
Research \\ Correlation between p16 and Interleukin-2 Gene Expression and Oral and Maxillofacial Wound Healing
}

\author{
ZHUO WEI WANG ${ }^{*}$, XUE JIU WANG ${ }^{1}$, K. Y. ZHANG ${ }^{1}$ AND H. Y. XIAN ${ }^{2}$
}

Department of Stomatology, Shunyi Hospital, Beijing Traditional Chinese Medicine Hospital, Shunyi, Beijing 101300, ${ }^{1}$ Department of Maxillofacial Trauma Orthognathic Surgery, Beijing Stomatological Hospital, Beijing 100050, ${ }^{2}$ Department of Ophthalmology, Beijing Shunyi Hospital, Beijing 101300, China

Wang et al.: Correlation between p16 and Interleukin-2 Gene Expression

\begin{abstract}
To analyze the relationship between p16 and interleukin-2 protein and messenger RNA levels and wound healing in patients with oral and maxillofacial trauma. 86 patients with oral and maxillofacial trauma were selected in our hospital from June 2018 to June 2020 and divided into good and poor trauma healing group. All patients were treated with vacuum sealing drainage and given empirical antibacterial antiinfective medication, nutritional support and correction of fluid-electrolyte disturbances for $7 \mathbf{d}$. Serum levels of inflammatory factors were measured before and after $7 \mathrm{~d}$ of treatment. The levels of interleukin-2, p16 and messenger RNA were measured by western blot and polymerase chain reaction. White blood cells, tumor necrosis factor alpha, interleukin-6, C-reactive protein and procalcitonin were lower in both groups than before treatment while the phosphorylated form of p16/p16, phosphorylated form of interleukin-2/ interleukin-2 proteins and messenger RNA levels were lower immediately after extubation $(\mathbf{p}<\mathbf{0 . 0 5})$. Pearson correlation analysis revealed that phosphorylated form of p16/p16 and phosphorylated form of interleukin-2/ interleukin-2 were significantly lower in the group immediately after extubation $(p<0.05)$. Phosphorylated form of p16/p16 and phosphorylated form of interleukin-2/interleukin-2 were positively correlated with white blood cells, tumor necrosis factor alpha, interleukin-6, C-reactive protein and procalcitonin after treatment $(\mathbf{p}<0.001)$. It is concluded that p16 and interleukin-2 in the drainage fluid of patients with oral and maxillofacial trauma can promote the process of wound healing by promoting the release of serum inflammatory factors.
\end{abstract}

Key words: Oral and maxillofacial trauma, p16, interleukin-2, trauma healing

Oral and maxillofacial space infection is a common infectious disease in department of stomatology and mainly occurs in the fascial space such as face, jaw, oropharyn $\mathrm{x}^{[1]}$. The disease progressed rapidly and easily spread to adjacent tissues and spaces, leading to multiple space infection, inducing severe complications such as descending necrotizing mediastinitis, respiratory obstruction, sepsis, etc., which seriously affected the prognosis of patients ${ }^{[2,3]}$. At present, patients with cavity and maxillofacial space infection are mainly treated with antibiotics combined with incision and drainage, in order to eliminate pus or infection secretion, remove pathogens, control infection and inflammatory process and promote wound healing ${ }^{[4]}$. However, the healing of infected wounds is affected by inflammatory factors, reactive oxygen species, persistent infection and other factors, which can lead to wound stagnation in the inflammatory phase and difficult to heal ${ }^{[5]}$. It is of great clinical significance to analyze the mechanism of wound healing in patients with oral and maxillofacial trauma, find sensitive molecular markers and guide the adjustment of clinical treatment plan.

P16 is one of the key proteins in the signaling pathway of inducing and maintaining chronic inflammation, which can regulate the release of a variety of inflammatory mediators ${ }^{[6]}$. Previous studies have shown that p16 plays a key role in wound repair, regulating the expression of inflammatory factors and participating in wound healing ${ }^{[7,8]}$. In addition, studies have shown that wound tissue healing is closely related to its immune status, such as T cell immunosuppression which is an important factor leading to infection and the decline

*Address for correspondence

E-mail: syyykq@163.com 
of wound tissue healing ability ${ }^{[9]}$. Interleukin-2 (IL2 ) gene expression and regulation play a key role in cellular trauma immunity. However, the role of p16 and IL-2 in wound healing in patients with oral and maxillofacial trauma is still unclear. Therefore, this study detected the expression levels of p16 and IL-2 in drainage fluid of patients with oral maxillofacial wound and further analyzed the relationship between the levels of p16 and IL-2 and wound healing, in order to provide a theoretical basis for clinical treatment of patients with oral maxillofacial wound.

\section{MATERIALS AND METHODS}

\section{Data:}

A total of 86 patients with oral and maxillofacial trauma in our hospital from June 2018 to June 2020 were selected as the research objects. According to the wound healing after $8 \mathrm{~d}$ of drainage, the patients were divided into good wound healing group $(\mathrm{n}=43)$ and poor wound healing group $(n=43)$. Wound healing criteria: $95 \%-100$ $\%$ of the wound epithelization or less than $5 \%$ of the residual wound by naked eye observation ${ }^{[10]}$. Inclusion criteria: All patients were over $18 \mathrm{y}$ old and met the relevant diagnostic criteria of oral and maxillofacial trauma in "nosocomial infection", with obvious red, swollen, hot and painful manifestations and positive bacterial culture of secretions of interstitial infection. Exclusion criteria: Patients with malignant tumor; patients with hypertension, coronary heart disease and diabetes mellitus; patients with severe heart, brain, liver and kidney dysfunction; patients with hematological or immune system diseases; patients with other site infection. This study was approved by the hospital ethics committee and all patients were informed and signed the informed consent.

\section{Treatment methods:}

All patients were treated with Vacuum Sealing Drainage (VSD). In addition, basic treatment such as empirical antibiotic anti-infection treatment, nutritional support and correction of water electrolyte disorder were given. After a $5 \mathrm{~cm}$ incision in the neck, the subcutaneous tissue was separated to the pus cavity and part of the pus was collected and sent to the microorganism room for bacterial culture and identification. A large amount of normal saline and iodophor were used to flush the pus cavity alternately. According to the size and shape of the abscess cavity, the VSD sponge was trimmed. The sponge, together with the negative pressure drainage tube and the flushing tube was placed into the infected wound cavity. The vacuum drainage $(20-40 \mathrm{kPa})$ was performed. The patients were treated with effective antibiotic flushing solution through flushing tube, 3 times a day. When the $24 \mathrm{~h}$ drainage volume is less than $10 \mathrm{ml}$, the tube can be pulled out.

\section{Identification of pathogens:}

According to the operation rules of clinical laboratory, the pus of the infection site was collected and placed in the sterile test tube. The pathogen was cultured and separated by the three line separation method. Vitek-32 automatic microorganism analyzer (BioMerieux, France) was used to identify pathogens. Quality control strain, Escherichia coli American Type Culture Collection (ATCC) 25922, Klebsiella pneumoniae ATCC 700603 and Staphylococcus aureus ATCC 25923 (clinical laboratory center of National Health Commission). If the same strain of bacteria is detected in the same patient's multiple samples, it is calculated as one strain.

\section{Laboratory testing:}

The age, gender, course of disease, source of infection and other general information of all subjects were recorded. Before and $7 \mathrm{~d}$ after treatment, 3-5 $\mathrm{ml}$ of fasting venous blood was collected from the patients with non-anticoagulant test tube and part of them were analyzed by Sysmex 5000i automatic hematology analyzer (Sysmex company, Japan). Another part of samples were centrifuged at $3500 \mathrm{r} / \mathrm{min}$ for $10 \mathrm{~min}$ to separate serum. Enzyme linked immunosorbent assay was used to detect serum Tumor Necrosis Factor alpha (TNF- $\alpha$ ), interleukin-6 (IL-6), and C-Reactive Protein (CRP) (Shanghai Jianglai Biotechnology Co., Ltd.). Serum Procalcitonin (PCT) level was measured by double antibody sandwich immunoluminescence assay (Shanghai Yuanmu Biotechnology Co., Ltd.). The wound healing time and granulation tissue growth time of all patients after drainage were recorded.

\section{Detection of p16 and IL-2 expression:}

The proteins expression of p16 and IL-2 was detected by western blot. 3-5 $\mathrm{ml}$ of drainage fluid was collected before and after catheter insertion, centrifuged at 3500 $\mathrm{r} / \mathrm{min}$ for $10 \mathrm{~min}$ and the supernatant was taken. The total protein was extracted by cell lysate and the protein concentration was detected. Then Sodium Dodecyl Sulphate-Polyacrylamide Gel Electrophoresis (SDSPAGE) was performed and membrane transferred to Polyvinylidene Fluoride (PVDF) membrane, placed in $5 \%$ Bovine Serum Albumin (BSA) at room temperature and closed for $2 \mathrm{~h}$, to give the primary antibody (p16 and IL-2, dilution ratio of 1:1000) incubated overnight 
at $4^{\circ}$, washed with horseradish peroxidase labeled two antibody (dilution ratio 1: 5000) incubated $2 \mathrm{~h}$ at room temperature. Electrochemiluminescence (ECL) was then used to display $\beta$-actin which was the internal parameter to analyze the band strength.

\section{Real time Polymerase Chain Reaction (RT-PCR):}

Total 3-5 $\mathrm{ml}$ of drainage fluid was collected at the time of catheterization and extubation respectively and centrifuged at $3500 \mathrm{r} / \mathrm{min}$ for $10 \mathrm{~min}$ before the supernatant was removed. Total RNA was extracted by Trizol method, complementary DNA (cDNA) was synthesized by reverse transcription kit and p16 messenger RNA (mRNA) was detected by RTPCR; Glyceraldehyde 3-Phosphate Dehydrogenase (GAPDH) was used as the internal reference. Primer sequences: p16, F: 5'-CCGAGGAGAACCTGTC-3', R: 5'-GCTTCTTCACTGCCACGACGATG-3'; IL-2, F: 5'-AACGCCACCGACGACTACA3', R: 5'-TGTCGAAGATCCGCAGCACCTT-3'.

\section{Statistical analysis:}

Statistical Package for the Social Sciences (SPSS) 20.0 software was used for data analysis. The measurement data of normal distribution were analyzed by t-test and present with mean \pm Standard Deviation (SD). The count data were analyzed by $\chi^{2}$ test and expressed as cases or percentages. Pearson correlation was used to analyze the relationship between p16 and IL-2 mRNA levels and serum inflammatory factors, $p<0.05$ was considered statistically significant.

\section{RESULTS AND DISCUSSION}

Comparison of basic characteristics of patients with oral and maxillofacial trauma is shown below. The wound healing time and granulation tissue growth time of patients with good wound healing group were significantly shorter than those of patients with poor wound healing group $(\mathrm{p}<0.001)$, as shown in Table 1 .

Pathogenic bacteria between the two groups were compared. A total of 65 strains of pathogens were detected in 43 patients with good wound healing and the main pathogens were Staphylococcus aureus, Klebsiella pneumoniae and Streptococcus pneumoniae. A total of 57 strains of pathogens were detected in 43 patients with poor wound healing and the main pathogens were Staphylococcus aureus, Klebsiella pneumoniae and Streptococcus pneumoniae. There was no significant difference in the distribution of pathogens between the two groups ( $p>0.05)$, as shown in Table 2 .

Serum inflammatory factors between the two groups were compared. The levels of White Blood Cells (WBC), TNF- $\alpha$, IL-6, CRP and PCT in the two groups after treatment were lower than those before treatment $(p<0.001)$. In addition, the levels of WBC, TNF- $\alpha$, IL- 6, CRP and PCT in patients with oral and maxillofacial trauma in the good wound healing group were significantly lower than those in the poor wound healing group ( $\mathrm{p}<0.001)$, as shown in Table 3 .

TABLE 1: CLINICAL DATA OF PATIENTS

\begin{tabular}{lccccc}
\hline Category & & Good healing group & Poor healing group & $\mathrm{t}$ & $\mathrm{P}$ \\
\hline Age $(\mathrm{y})$ & & $50.84 \pm 10.33$ & $52.91 \pm 10.46$ & 0.999 & 0.320 \\
Gender $(\mathrm{n})$ & Male & 32 & 26 & 0.027 & 0.868 \\
& Female & 25 & 19 & & \\
& & $22.75 \pm 2.16$ & $22.30 \pm 2.28$ & 1.042 & 0.300 \\
BMI $\left(\mathrm{kg} / \mathrm{m}^{2}\right)$ & & $6.83 \pm 0.87$ & $9.42 \pm 1.41$ & 11.397 & $<0.001$ \\
$\begin{array}{l}\text { Wound healing time } \\
\text { (d) }\end{array}$ & & $19.85 \pm 3.26$ & $24.37 \pm 4.15$ & 6.162 & $<0.001$ \\
$\begin{array}{l}\text { When granulation } \\
\text { tissue grows (d) }\end{array}$ & & & & \\
$\begin{array}{l}\text { Source of infection } \\
\text { (n) }\end{array}$ & Odontogenic & 27 & 24 & 0.301 & 0.860 \\
& Glandular & 10 & 12 & & \\
& Others & 6 & 7 & & \\
\hline
\end{tabular}


TABLE 2: DISTRIBUTION OF PATHOGENS IN PATIENTS WITH ORAL AND MAXILLOFACIAL TRAUMA

\begin{tabular}{|c|c|c|c|c|}
\hline \multirow{2}{*}{ Pathogenic bacteria } & \multicolumn{2}{|c|}{ Good healing group } & \multicolumn{2}{|c|}{ Poor healing group } \\
\hline & Bacterial strain & Constituent ratio (\%) & Bacterial strain & Constituent ratio (\%) \\
\hline Gram positive bacteria & 45 & 69.23 & 34 & 59.65 \\
\hline Staphylococcus aureus & 32 & 49.23 & 21 & 36.84 \\
\hline Streptococcus pneumoniae & 9 & 13.84 & 7 & 12.28 \\
\hline Staphylococcus epidermidis & 7 & 10.77 & 4 & 7.02 \\
\hline Staphylococcus haemolyticus & 2 & 3.09 & 2 & 3.51 \\
\hline Gram negative bacteria & 20 & 30.77 & 23 & 40.35 \\
\hline Klebsiella pneumoniae & 12 & 18.46 & 11 & 19.30 \\
\hline Pseudomonas aeruginosa & 6 & 9.23 & 7 & 12.28 \\
\hline Escherichia coli & 5 & 7.69 & 3 & 5.66 \\
\hline Others & 2 & 3.09 & 2 & 3.51 \\
\hline
\end{tabular}

TABLE 3: COMPARISON OF SERUM INFLAMMATORY FACTORS BETWEEN THE TWO GROUPS

\begin{tabular}{|c|c|c|c|c|c|c|c|c|c|c|}
\hline \multirow[b]{2}{*}{ Index } & \multicolumn{4}{|c|}{ Good healing group } & \multicolumn{2}{|c|}{ Poor healing group } & \multirow{2}{*}{\multicolumn{4}{|c|}{$\mathrm{p}$}} \\
\hline & $\begin{array}{c}\text { Before } \\
\text { treatment }\end{array}$ & $\begin{array}{c}\text { After } \\
\text { treatment }\end{array}$ & & $\mathrm{p}$ & $\begin{array}{c}\text { Before } \\
\text { treatment }\end{array}$ & $\begin{array}{c}\text { After } \\
\text { treatment }\end{array}$ & & & & \\
\hline WBC (109/l) & $12.24 \pm 2.47$ & $9.52 \pm 2.25$ & $2.75 \pm 0.88$ & $<0.001$ & $12.37 \pm 2.36$ & $10.27 \pm 2.15$ & $2.08 \pm 0.62$ & $<0.001$ & 0.788 & $<0.001$ \\
\hline TNF-a (ng/l) & $48.24 \pm 9.68$ & $26.31 \pm 5.71$ & $21.91 \pm 6.84$ & $<0.001$ & $47.65 \pm 8.92$ & $33.56 \pm 7.64$ & $14.11 \pm 3.16$ & $<0.001$ & 0.752 & $<0.001$ \\
\hline IL-6 (ng/l) & $65.53 \pm 11.59$ & $32.46 \pm 8.24$ & $33.04 \pm 8.96$ & $<0.001$ & $62.91 \pm 10.44$ & $48.21 \pm 9.55$ & $14.72 \pm 3.25$ & $<0.001$ & 0.239 & $<0.001$ \\
\hline CRP (mg/l) & $32.59 \pm 7.93$ & $18.57 \pm 4.06$ & $14.05 \pm 3.28$ & $<0.001$ & $33.47 \pm 8.05$ & $24.71 \pm 6.21$ & $8.74 \pm 2.11$ & $<0.001$ & 0.582 & $<0.001$ \\
\hline IVT (Ig/l) & $3.16 \pm 0.85$ & $1.15 \pm 0.34$ & $1.98 \pm 0.52$ & $<0.001$ & $3.20 \pm 0.90$ & $1.67 \pm 0.52$ & $1.55 \pm 0.50$ & $<0.001$ & 0.819 & $<0.001$ \\
\hline
\end{tabular}

The expression of p16 and IL-2 protein in drainage fluid of the two groups was compared. The protein levels of phosphorylated form of p16 (p-p16)/p16 and phosphorylated form of interleukin-2 (p-IL-2)/IL-2 before extubation in both groups were lower than those immediately after intubation $(\mathrm{p}<0.001)$. In addition, the protein levels of p-p16/p16 and p-IL-2/IL-2 in patients with oral and maxillofacial trauma in the well wound healing group were lower than those in the poor wound healing group $(\mathrm{p}<0.001)$. As shown in fig. 1 and Table 4 .
Comparison of p16 and IL-2 mRNA levels in drainage fluid between the two groups was shown below. The expression of p16 and IL-2 mRNA immediately before extubation in both groups was significantly lower than that immediately after intubation $(\mathrm{p}<0.001)$. In addition, immediately after extubation, the p16 and IL-2 mRNA levels of patients with oral and maxillofacial trauma in good wound healing group were lower than those in poor wound healing group $(\mathrm{p}<0.001)$, as shown in fig. 2 and Table 5.

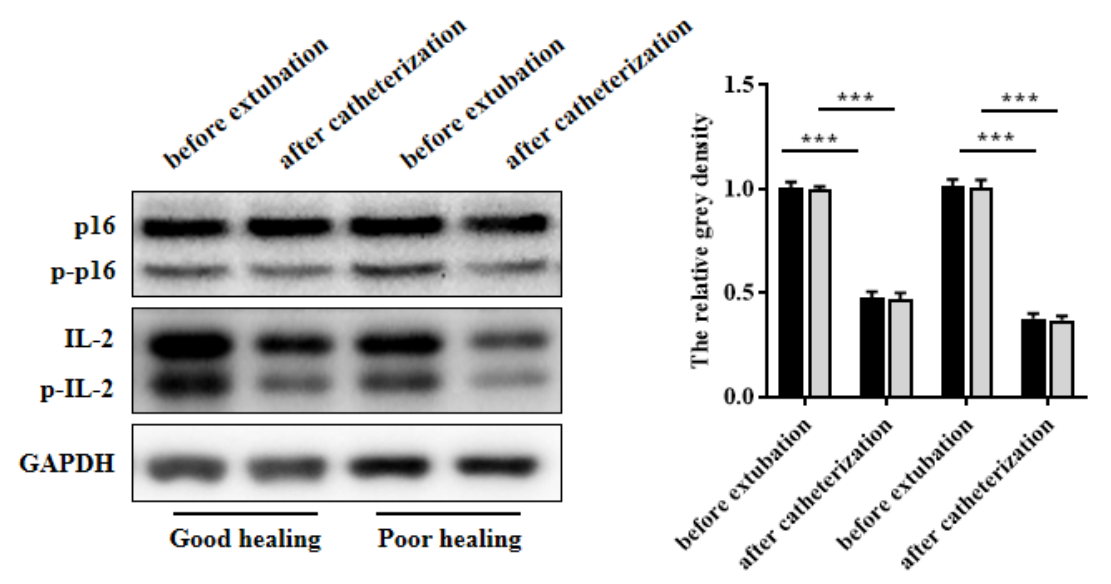

Fig. 1: Expression of p16 and IL-2 protein in drainage fluid of two groups, ( $)$ ) p-p16/p16; ( $\square$ ) p-IL-2/IL-2 
TABLE 4: COMPARISON OF THE EXPRESSION OF p16 AND IL-2 PROTEIN IN DRAINAGE FLUID OF THE TWO GROUPS

\begin{tabular}{|c|c|c|c|c|c|c|c|c|c|c|}
\hline \multirow[b]{2}{*}{ Index } & \multicolumn{4}{|c|}{ Good healing group } & \multicolumn{2}{|c|}{ Poor healing group } & & \multirow[b]{2}{*}{$\mathrm{p}$} & \multirow[b]{2}{*}{ p } & \\
\hline & $\begin{array}{c}\text { Immediately } \\
\text { after } \\
\text { catheterization }\end{array}$ & $\begin{array}{l}\text { Immediately } \\
\text { before } \\
\text { extubation }\end{array}$ & & $\mathrm{p}$ & $\begin{array}{c}\text { Immediately } \\
\text { after } \\
\text { catheterization }\end{array}$ & $\begin{array}{c}\text { Immediately } \\
\text { before } \\
\text { extubation }\end{array}$ & & & & \\
\hline p16 & $0.78 \pm 0.11$ & $0.62 \pm 0.09$ & $0.16 \pm 0.04$ & $<0.001$ & $0.79 \pm 0.10$ & $0.65 \pm 0.10$ & $0.14 \pm 0.04$ & $<0.001$ & 0.636 & 0.014 \\
\hline p-p16 & $0.55 \pm 0.09$ & $0.31 \pm 0.06$ & $0.24 \pm 0.07$ & $<0.001$ & $0.57 \pm 0.09$ & $0.40 \pm 0.08$ & $0.17 \pm 0.03$ & $<0.001$ & 0.268 & $<0.001$ \\
\hline $\begin{array}{l}\text { p-p16/ } \\
\text { p16 }\end{array}$ & $0.71 \pm 0.10$ & $0.50 \pm 0.08$ & $0.21 \pm 0.04$ & $<0.001$ & $0.69 \pm 0.08$ & $0.61 \pm 0.07$ & $0.08 \pm 0.02$ & $<0.001$ & 0.277 & $<0.001$ \\
\hline IL-2 & $0.64 \pm 0.09$ & $0.56 \pm 0.08$ & $0.09 \pm 0.03$ & $<0.001$ & $0.65 \pm 0.09$ & $0.56 \pm 0.09$ & $0.08 \pm 0.03$ & $<0.001$ & 0.579 & 0.098 \\
\hline $\mathrm{P}-\mathrm{IL}-2$ & $0.52 \pm 0.08$ & $0.30 \pm 0.07$ & $0.22 \pm 0.06$ & $<0.001$ & $0.54 \pm 0.08$ & $0.40 \pm 0.07$ & $0.14 \pm 0.03$ & $<0.001$ & 0.213 & $<0.001$ \\
\hline $\begin{array}{l}\text { p-IL- } \\
2 / I L-2\end{array}$ & $0.81 \pm 0.12$ & $0.54 \pm 0.08$ & $0.28 \pm 0.04$ & $<0.001$ & $0.83 \pm 0.13$ & $0.70 \pm 0.09$ & $0.13 \pm 0.04$ & $<0.001$ & 0.422 & $<0.001$ \\
\hline
\end{tabular}

Fig. 2: Expression of p16 and IL-2 protein in drainage fluid of two groups, ( $(\square)$ p16; (ص) IL-2

TABLE 5: COMPARISON OF p16 AND IL-2 mRNA LEVELS IN DRAINAGE FLUID BETWEEN THE TWO GROUPS

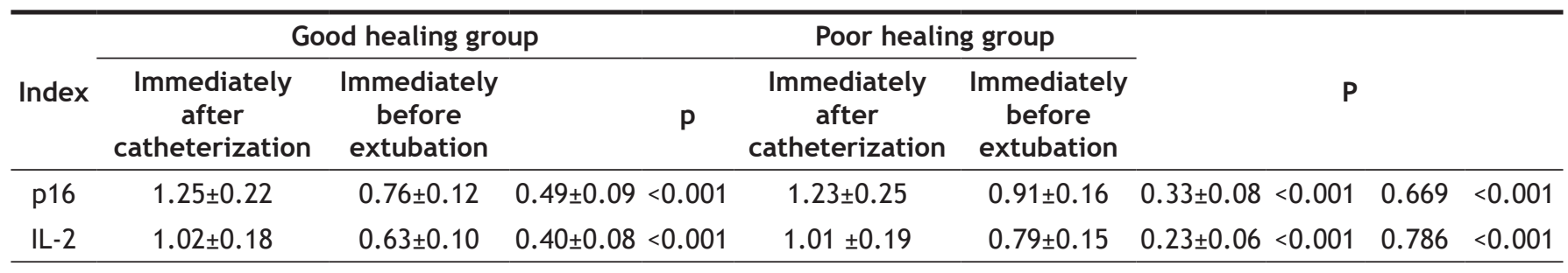

Relationship between phosphorylation of p16 and IL-2 in drainage fluid and serum inflammatory factors in two groups was shown here. Pearson correlation analysis showed that the levels of p-p16/p16 and p-IL-2/IL-2 in drainage fluid immediately after extubation were positively correlated with WBC, TNF- $\alpha$, IL-6, CRP and PCT after treatment $(\mathrm{p}<0.05)$, as shown in Table 6. 
TABLE 6: RELATIONSHIP BETWEEN PHOSPHORYLATION OF p16 AND IL-2 IN DRAINAGE FLUID AND SERUM INFLAMMATORY FACTORS IN TWO GROUPS

\begin{tabular}{lcccc}
\hline \multirow{2}{*}{ Index } & $\mathrm{p}-\mathrm{p} 16 / \mathrm{p} 16$ & $\mathrm{p}-\mathrm{IL}-2 / \mathrm{IL}-2$ & $1.01 \pm 0.19$ & $\mathbf{1 . 0 1 \pm 0 . 1 9}$ \\
\cline { 2 - 5 } & $\mathrm{r}$ & $\mathrm{p}$ & $\mathrm{r}$ & $\mathrm{p}$ \\
\hline WBC & 0.347 & 0.001 & 0.325 & 0.001 \\
TNF-a & 0.421 & $<0.001$ & 0.406 & $<0.001$ \\
IL-6 & 0.436 & $<0.001$ & 0.418 & $<0.001$ \\
CRP & 0.441 & $<0.001$ & 0.422 & $<0.001$ \\
PCT & 0.286 & 0.003 & 0.263 & 0.006 \\
\hline
\end{tabular}

Note: $r$ represents correlation coefficient

Oral and maxillofacial space infection is an acute inflammatory disease caused by odontogenic, glandular and traumatic infections. Although the current open negative pressure sealing drainage combined with antimicrobial therapy can effectively remove the exudates in the wound cavity and control the process of infection and inflammation, the treatment effect of some patients is still not very idea ${ }^{[11]}$. Infection pathogens can cause purulent inflammation by invading potential space and the infection is easy to spread to surrounding tissue space, causing multi space inflammatory injury ${ }^{[12]}$. This study found that there was no significant difference in the distribution of pathogens between the two groups and the main pathogens of infection were Staphylococcus aureus, Klebsiella pneumoniae and Streptococcus pneumoniae, suggesting that there was no significant relationship between the distribution of pathogens and wound healing in patients with oral and maxillofacial trauma. P16/IL-2 signaling pathway is one of the important signaling pathways for the body to regulate the chronic inflammatory response, which can regulate the release of a variety of inflammatory mediators and play an important role in the process of wound repair and wound healing ${ }^{[13,14]}$. Therefore, this study further detected the expression levels of p16 and IL-2 in the drainage fluid of patients with oral and maxillofacial trauma, providing a theoretical basis for clinical treatment.

We found that the level of WBC, TNF- $\alpha$, IL-6, CRP and PCT in the group with good wound healing and the group with poor wound healing after treatment was significantly lower than that before treatment. In addition, the levels of the above indicators in the patients with good wound healing group decreased more significantly after treatment, suggesting that the wound healing of patients with oral and maxillofacial trauma is related to the changes of serum inflammatory factors. As one of the most important inflammatory factors in the body, TNF- $\alpha$ can induce the release of
IL-6 and other inflammatory mediators downstream, thus affecting the wound healing process of burn ${ }^{[15]}$, infection ${ }^{[16]}$, surgery ${ }^{[17]}$. IL-6 participates in the process of immune inflammatory response, mediates tissue repair and can also induce the synthesis of CRP in acute phase, which aggravates the immune inflammatory injury of the body ${ }^{[18]}$. CRP is a non-specific protein to evaluate the severity of infection or tissue trauma, which can be used for clinical evaluation of wound healing in patients with burn infection ${ }^{[19]}$. PCT level changes can reflect the process of bacterial infection ${ }^{[20]}$ and can be used to evaluate the wound healing. Previous studies have shown that wound healing is a process involving inflammatory factors and cytokines. TNF- $\alpha$, IL- 6 and other inflammatory mediators are the main factors affecting the wound healing of chronic infection, which indicates that it is necessary to monitor the serum inflammatory factor levels of patients with oral and maxillofacial trauma, adjust the treatment plan in time, control the infection and inflammatory process and promote wound healing ${ }^{[21]}$.

In this study, the protein and mRNA expressions of p-p16/p16 and p-IL-2/IL-2 in the two groups were significantly lower immediately before extubation than immediately after intubation. In addition, the levels of all indexes decreased more significantly in the group with good wound healing immediately after extubation, suggesting that p16 and IL-2 phosphorylation participate in the regulation of wound healing process in patients with oral and maxillofacial trauma. P16/IL-2 signaling pathway can regulate the body's chronic inflammatory process and participate in the occurrence and development of a variety of inflammatory diseases ${ }^{[22]}$. Studies have shown that TNF- $\alpha$, IL- 6 and other inflammatory mediators can activate the phosphorylation of p16 and the activated p16 can promote the release of TNF- $\alpha$, IL- 6 and other inflammatory factors, further aggravating the body's inflammatory response ${ }^{[23]}$. IL-2 is also one of the 
substrates of $\mathrm{p} 16$, activated $\mathrm{p} 16$ can phosphorylate IL-2 and regulate the expression of inflammatory factors, cell growth and migration factors. P16/IL-2 signaling pathway can regulate the release of inflammatory factors and affect the wound healing. In accordance with the above results, the phosphorylation of p16 and IL-2 may affect the wound healing of patients with oral and maxillofacial trauma by regulating the level of serum inflammatory factors. In this study, the levels of p-p16/ p16 and p-IL-2/IL-2 in drainage fluid immediately after catheterization were significantly positively correlated with the levels of WBC, TNF- $\alpha$, IL-6, CRP and PCT after treatment, which further confirmed that $\mathrm{p} 16 /$ IL-2 signaling pathway can affect the levels of serum inflammatory factors and wound healing.

In conclusion, the levels of serum inflammatory factors and the expressions of p-p16/p16 and p-IL-2/IL-2 in drainage fluid in patients with good wound healing were significantly lower than those in patients with poor wound healing. In addition, p-p16/p16 and p-IL-2/ IL-2 in drainage fluid were significantly correlated with serum inflammatory factors. Clinically, according to the changes of serum inflammatory factors in patients with oral and maxillofacial trauma, we can evaluate the degree of wound healing and guide clinical treatment.

\section{Acknowledgements:}

This work was supported by the Shunyi Hospital, Beijing Traditional Chinese Medicine Hospital.

\section{Conflicts of interest:}

The authors reported that there is no conflict of interest.

\section{REFERENCES}

1. Erickson S, Sangfelt O, Heyman M, Castro J, Einhorn S, Grander D. Involvement of the Ink4 proteins p16 and p15 in T-lymphocyte senescence. Oncogene 1998;17(5):595-602.

2. Fujiwara H, Arima N, Hashimoto-Tamaoki T, Matsushita K, Ohtsubo H, Arimura K, et al. Alteration of p16 (CDKN2) gene is associated with interleukin-2-induced tumor cell growth in adult T-cell leukemia. Exp Hematol 1999;27(6):1004-9.

3. Basso FG, Pansani TN, Turrioni AP, Soares DG, de Souza Costa CA, Hebling J. Tumor necrosis factor- $\alpha$ and interleukin (IL)-1 $\beta$, IL-6, and IL-8 impair in vitro migration and induce apoptosis of gingival fibroblasts and epithelial cells, delaying wound healing. J Periodontol 2016;87(8):990-6.

4. Touch S, Clement K, Andre S. T cell populations and functions are altered in human obesity and type 2 diabetes. Curr Diab Rep 2017;17(9):1-8.

5. Menon MB, Gropengießer J, Fischer J, Novikova L, Deuretzbacher A, Lafera J, et al. p38 MAPK/MK2-dependent phosphorylation controls cytotoxic RIPK1 signalling in inflammation and infection. Nat Cell Biol 2017;19(10):124859.
6. Marabondo S, Kaufman HL. High-dose interleukin-2 (IL2) for the treatment of melanoma: safety considerations and future directions. Expert Opin Drug Saf 2017;16(12):1347-57.

7. Mitra S, Leonard WJ. Biology of IL-2 and its therapeutic modulation: Mechanisms and strategies. J Leukoc Biol 2018;103(4):643-55.

8. Bosquet A, Girona J, Guaita-Esteruelas S, Heras M, Saavedra-Garcia P, Martinez-Micaelo N, et al. FABP4 inhibitor BMS309403 decreases saturated-fatty-acid-induced endoplasmic reticulum stress-associated inflammation in skeletal muscle by reducing p38 MAPK activation. Biochim Biophys Acta Mol Cell Biol Lipids 2018;1863(6):604-13.

9. Zhang B, Huang YQ, Cao QZ, Lin JQ, Wang YY, Zheng DY. A preliminary observation of implanting a double-eyelet capsular tension ring in eyes with serious lens subluxation. Chin J Ophthalmol 2018;54(5):343-8.

10. Otterco AN, Brassolatti P, Andrade AL, Avo LR, Bossini PS, Parizotto NA. Effect of photobiomodulation $(670 \mathrm{~nm})$ associated with vitamin A on the inflammatory phase of wound healing. Lasers Med Sci 2018;33(9):1867-74.

11. Wu J, Yang J, Wang X, Wei L, Mi K, Shen Y, et al. A frog cathelicidin peptide effectively promotes cutaneous wound healing in mice. Biochem J 2018;475(17):2785-99.

12. Frydrych LM, Bian G, O'Lone DE, Ward PA, Delano MJ. Obesity and type 2 diabetes mellitus drive immune dysfunction, infection development, and sepsis mortality. J Leukoc Biol 2018;104(3):525-34.

13. Christensen BJ, Park EP, Nelson S, King BJ. Are emergency medicine physicians able to determine the need for computed tomography and specialist consultation in odontogenic maxillofacial infections? J Oral Maxillofac Surg 2018;76(12):2559-63.

14. Mizui M. Natural and modified IL-2 for the treatment of cancer and autoimmune diseases. Clin Immunol 2019;206:63-70.

15. Qiu Y, Li Y, Gao B, Li J, Pan L, Ye Z, et al. Therapeutic efficacy of vacuum sealing drainage-assisted irrigation in patients with severe multiple-space infections in the oral, maxillofacial, and cervical regions. J Craniomaxillofac Surg 2019;47(5):837-41.

16. Ahmad A, Herndon DN, Szabo C. Oxandrolone protects against the development of multiorgan failure, modulates the systemic inflammatory response and promotes wound healing during burn injury. Burns 2019;45(3):671-81.

17. Kanareikina MA, Alinkina ES, Petrova AO, Emel'yanova AG, Gorbunov EA, Tarasov SA. Ergoferon Increases IL-2 Production by Activated Lymphocytes. Bull Exp Biol Med 2019;166(4): 744-6.

18. Schneider A, Gorr IH, Larraillet V, Frensing T, Popp O. Reduction of IL-2 fragmentation during manufacturing of a novel immunocytokine by DoE process optimization. Biotechnol Bioeng 2019;116(10):2503-13.

19. Keswani ES, Venkateshwar G. Odontogenic maxillofacial space infections: a 5-year retrospective review in Navi Mumbai. J Maxillofac Oral Surg 2019;18(3):345-53.

20. Cao G, Lei L, Zhu X. Efficiency and safety of autologous chimeric antigen receptor T-cells therapy used for patients with lymphoma: A systematic review and meta-analysis. Medicine 2019;98(42):e17506.

21. Dai TG, Ran HB, Qiu YX, Xu B, Cheng JQ, Liu YK. Fatal complications in a patient with severe multi-space infections in the oral and maxillofacial head and neck regions: A case report. World J Clin Cases 2019;7(23):4150-6. 
22. Chawla AS, Khalsa JK, Dhar A, Gupta S, Umar D, Arimbasseri GA, et al. A role for cell-autocrine interleukin-2 in regulatory T-cell homeostasis. Immunology 2020;160(3):295-309.

23. Wu R, Li N, Zhao X, Ding T, Xue H, Gao C, et al. Low-dose Interleukin-2: Biology and therapeutic prospects in rheumatoid arthritis. Autoimmun Rev 2020:102645.
This is an open access article distributed under the terms of the Creative Commons Attribution-NonCommercial-ShareAlike 3.0 License, which allows others to remix, tweak, and build upon the work non-commercially, as long as the author is credited and the new creations are licensed under the identical terms

This article was originally published in a special issue, "Diagnostic and Therapeutic Advances in Biomedical Research and Pharmaceutical Sciences"

Indian J Pharm Sci 2021:83(5) spl issue "169-176" 